RESEARCH PAPER RP1659

Part of Journal of Research of the National Bureau of Standards, Volume 34, June 1945

\title{
REFRACTIVE-INDEX STANDARDS OF FLUORCROWN GLASS
}

\author{
By Leroy W. Tilton
}

\section{ABSTRACT}

Refractive-index samples of fluorcrown glass, which provide solid standards in the index range between fused quartz, $n_{D}=1.458$, and low index silicate crown glass, $n_{D}=1.51$, are characterized by very low temperature coefficients of index, and thus are especially recommended for use at extreme room temperatures. The calibration of such standards may be facilitated by comparisons with the precise data herein tabulated for six of these glasses in the temperature range $15^{\circ}$ to $55^{\circ} \mathrm{C}$. Because of surface weathering, repolishings are sometimes necessary to avoid hazy and possibly false critical border lines. In some cases bright bands appear in the dark portion of the refractometer field. These are interpreted as critical-angle phenomena corresponding to decomposition products in the surface layers.

\section{CONTENTS}

I. Introduction

II. Description of prismatic standards

III. Refractive-index data

I V. Surface instability

V. Effect of temperature on resonance frequency

\section{INTRODUCTION}

The refractive-index range 1.45 to 1.50 , in which comparatively few solid standards are available, is important on the scales of commercial refractometers because so many oils, fats, and other liquids are included. Although this interval is relatively small on instruments of the Abbe type, it includes a large and much-used portion of the Butyro refractometer scale and all modern dipping refractometers with detachable prisms provide adequately for index measurements within this range.

The makers of refractometers usually supply only one test slab or test specimen to be used in adjusting a given refractometer. For the Abbe type, with its wide index range, a piece of optical crown glass with index at least as high as 1.5 is customarily supplied, and on the Butyro type the scale extends so low that fluorite can be used for adjustments if one is not satisfied with the fluid that is sometimes furnished. The immersion refractometers can cover this index range witb two of the interchangeable prisms so designed that one is adjusted at the lower end of its scale by means of fluorite and the other prism adjusted at the upper end of its scale by a piece of borosilicate crown glass with low index. 
In order, however, that anyone may adequately check the accuracy of a Butyro scale, or the corresponding prisms of an immersion refractometer, it is highly desirable to have a number of standard test specimens in this much-used range of 1.45 to 1.50 in refractive index. For such purposes solid standards are preferable to liquids because of their lower temperature coefficients of refractivity and relatively greater permanence, stability, and freedom from contamination. Since, moreover, there has been no satisfactory specification of the exact conditions under which liquid and solid standards may be used interchangeably, fluorcrown glasses are desirable for research purposes in precise refractometry.

\section{DESCRIPTION OF PRISMATIC STANDARDS}

In the refractometric laboratory at this Bureau, 13 refractiveindex standards of fluorcrown glass have been in use for several years. They are made in the form of 60-degree prisms to provide for accurate measurements by the method of minimum deviation. By grinding and polishing a small area near one edge each prism is so modified ${ }^{1}$ that a 90-degree intersection between polished faces is effected, and thus the prism may be used as a test slab on any refractometer provided the cement or metal in which a refractometer block is mounted does not project above the plane of the polished surface of the glass block. The faces of these prisms are of three sizes, 10 by 25,12 by 30 , and 24 by $24 \mathrm{~mm}$. Small size of face is of particular importance whenever the cement or metal does project above the glass block.

The glasses for these prisms were purchased through two or three different agencies but were, perhaps, all made at Jena, Germany. These prisms represent as many as six, and possibly seven, separate melts of glass. The data for glass A depend on only one prism but for the other glasses the data are averages for duplicate prisms. Glass $\mathrm{A}$ is somewhat lower in index than any now listed in the Schott \& Gen. catalog. Glass B was purchased in the United States and glass C procured directly from Jena, but they differ so little that these two glasses may be originally from the same melt. Accordingly, their data have been averaged. Certainly glasses B and C closely resemble the Schott glass 0.7185 or, as more recently designated, FK3. Glass D corresponds to Schott's old designation 0.6500 , or FK1. Glass $\mathrm{E}$ differs from the others included in this study and may not be a fluorcrown glass. It resembles the more usual silica glasses in that it has a decidedly positive temperature coefficient of refractive index. It is almost identical with Schott's FK4, which, in turn, however, is almost identical with their old designation 0.3258 that was styled "Borosilikat Cron," without reference to fluorine. Incidentally, Schott's FK4 is omitted in Glastechnische Tabellen (Berlin 1932) where, on page 314 , the fluorcrown glasses FK1,2, 3, and 5 are listed. Glass $\mathrm{F}$ is probably very similar to Schott's FK2 and to FK5; glass" $\mathrm{G}$ appears almost identical with their old designation 0.6781 .

${ }^{1}$ See illustration, p. 623, BS J. Research 3 (1929) RP112; also p. 372, J. Opt. Soc. Am. 32 (1942). 


\section{REFRACTIVE-INDEX DATA}

Refractive-index data on these standard prisms are given in tables 1 to 6 . The measurements were made by the method of minimum deviation on a spectrometer with a special constant-temperature prism housing that has been described in a former paper. ${ }^{2}$ A feature of the work on these prisms with this apparatus is the determination of their temperature coefficients of index by precise observations at temperatures near those at which the standards are to be used. Although the imprecision of these observed data is about $\pm 13 \times 10^{-7}$, it is thought that the graduated data as tabulated are precisely smoothed to about $\pm 2 \times 10^{-7}$, except at the corners of the tables.

TABLE 1.-Temperature variations in refractivity of fluorcrown glass $(A)$, the values being smoothed by the item-differences method; average imprecision, observed minus smoothed index, is $\pm 12 \times 10^{-7}$

$$
\left[\Delta n=\left(n_{t_{g}}-n_{t_{1}}\right) \times 10^{7}\right]
$$

Heavy rules in $\Delta n$ columns are located approximately opposite the temperatures of minimum index.

\begin{tabular}{|c|c|c|c|c|c|c|c|c|c|c|}
\hline \multirow{3}{*}{$\begin{array}{l}\text { Tem- } \\
\text { pera- } \\
\text { ture } \\
\left({ }^{\circ} \mathrm{C}\right)\end{array}$} & \multicolumn{8}{|c|}{ Refractive index (referred to dry air at $t^{\circ} \mathrm{C}$ and pressure of $760 \mathrm{~mm}$ of $\mathrm{Hg}$ ) } & \multicolumn{2}{|c|}{ Dispersion } \\
\hline & \multicolumn{2}{|c|}{$\lambda=6562.8 \mathrm{~A}$} & \multicolumn{2}{|c|}{$\lambda=5893 \mathrm{~A}$} & \multicolumn{2}{|c|}{$\lambda=4861.3 \mathrm{~A}$} & \multicolumn{2}{|c|}{$\lambda=4340.5 \mathrm{~A}$} & \multirow{2}{*}{$\nu=\frac{n_{D}-1}{n_{F}-n_{C}}$} & \multirow{2}{*}{$\begin{array}{c}\Delta \nu \\
\text { for } \\
1^{\circ} \mathrm{C}\end{array}$} \\
\hline & $n_{C}$ & $\begin{array}{c}\Delta n \text { for } \\
1^{\circ} \mathrm{C}\end{array}$ & $n_{D}$ & $\begin{array}{l}\Delta n \text { for } \\
1^{\circ} \mathrm{C}\end{array}$ & $n_{F}$ & $\begin{array}{l}\Delta n \text { for } \\
1^{\circ} \mathrm{C}\end{array}$ & $n_{G^{\prime}}$ & $\begin{array}{l}\Delta n \text { for } \\
1^{\circ} \mathbf{C}\end{array}$ & & \\
\hline \multirow{7}{*}{$\begin{array}{l}55 \\
50 \\
45 \\
40 \\
35 \\
30 \\
25 \\
20 \\
15\end{array}$} & 1. 4590118 & \multirow{2}{*}{+3.4} & 1. 4610931 & \multirow{2}{*}{+4.8} & 1. 4659489 & \multirow{2}{*}{+6.3} & 1. 4697922 & \multirow{2}{*}{+9.2} & 66.468 & \multirow{2}{*}{-0.0027} \\
\hline & \multirow[t]{2}{*}{1.4590084} & & 1. 4610883 & & 1. 4659426 & & \multirow{2}{*}{ 1. 4697830} & & \multirow{2}{*}{66.495} & \\
\hline & & -0.9 & & \multirow{3}{*}{$\begin{array}{c}+0.7 \\
-1.2\end{array}$} & & \multirow{2}{*}{+2.7} & & +7.2 & & -.0034 \\
\hline & \multirow{2}{*}{ 1. 4590093} & . & 1. 4610876 & & 1.4659399 & & 1.4697758 & & 66.529 & \\
\hline & & \multirow{2}{*}{-5.0} & 1.4610888 & & 1. 4659389 & +1.0 & \multirow[t]{2}{*}{1.4697703} & +5.5 & 66.567 & \multirow{2}{*}{$\begin{array}{r}-.0038 \\
\hdashline-.0036\end{array}$} \\
\hline & 1. 4590122 & & & -3.3 & & -1.3 & & +3.3 & & \\
\hline & 1. 4590172 & $-\cdots$ & 1. 4610921 & & 1. 4659402 & & 1.4697670 & & 66.603 & \\
\hline
\end{tabular}

TABLE 2.-Temperature variations in refractivity of fluorcrown glasses ( $B$ and $C$ ) resembling Schott \& Gen. FK3 or 0.7185 (values smoothed by the item-differences method from averaged data on four prisms; average imprecision, observed minus smoothed index, is $\pm 8 \times 10^{-7}$ )

$$
\left[\Delta n=\left(n_{l_{2}}-n_{\ell_{1}}\right) \times 10^{\eta}\right]
$$

\begin{tabular}{|c|c|c|c|c|c|c|c|c|c|c|}
\hline \multirow{3}{*}{$\begin{array}{l}\text { Tem- } \\
\text { pera- } \\
\text { ture } \\
\left({ }^{\circ} \mathrm{C}\right)\end{array}$} & \multicolumn{8}{|c|}{ Refractive index (referred to dry air at $t^{\circ} \mathrm{C}$ and pressure of $760 \mathrm{~mm}$ of $\mathrm{Hg}$ ) } & \multicolumn{2}{|c|}{ Dispersion } \\
\hline & \multicolumn{2}{|c|}{$\lambda=6562.8 \mathrm{~A}$} & \multicolumn{2}{|c|}{$\lambda=5893 \mathrm{~A}$} & \multicolumn{2}{|c|}{$\lambda=4861.3 \mathrm{~A}$} & \multicolumn{2}{|c|}{$\lambda=4340.5 \mathrm{~A}$} & \multirow{2}{*}{$\nu=\frac{n_{D}-1}{n_{P}-n_{C}}$} & \multirow{2}{*}{$\begin{array}{c}\Delta \nu \\
\text { for } \\
1^{\circ} \mathrm{C}\end{array}$} \\
\hline & $n_{c}$ & $\begin{array}{l}\Delta n \text { for } \\
1^{\circ} \mathrm{C}\end{array}$ & $n_{D}$ & $\Delta n$ for & $n_{P}$ & $\Delta n$ for & $n_{\sigma^{\prime}}$ & $\begin{array}{l}\Delta n \text { for } \\
1^{\circ}{ }_{\Delta} \mathrm{C}\end{array}$ & & \\
\hline \multirow{6}{*}{$\begin{array}{l}55 \\
50 \\
45 \\
40 \\
35 \\
30 \\
25 \\
20 \\
15\end{array}$} & 1.4601175 & \multirow{2}{*}{-13.7} & 1.4622202 & \multirow{2}{*}{-12.3} & 1. 4671402 & \multirow{2}{*}{-10.0} & 1. 4710567 & \multirow{2}{*}{-6.4} & \multirow{2}{*}{\multicolumn{2}{|c|}{-0.0036}} \\
\hline & 1.4601312 & & 1.4622325 & & 1.4671502 & & 1.4710631 & & & \\
\hline & 1. 4601483 & -17.1 & 1.4622488 & - & 1.4671650 & -14.8 & 1.4710732 & -10.1 & 65.878 & -.002 \\
\hline & & -18.4 & & -17.7 & & -16.4 & & -11.5 & & \multirow{2}{*}{-.002} \\
\hline & 1. 4601667 & -18.6 & 1.4622665 & 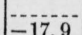 & 1. 4671814 & -16.6 & 1.4710847 & \multirow{2}{*}{-11.7} & 65.900 & \\
\hline & 1.4601853 & -10.0 & 1.4622844 & -1... & 1.4671980 & - & 1.4710964 & & 65.921 & \\
\hline
\end{tabular}

2 J. Research NBS 17, 389(1936) RP919. 
TABLE 3.-Temperature variations in refractivity of fuorcrown glass $(D)$ resembling Schott \& Gen. FK1 or 0.6500 (values smoothea by the itemdifferences method from averaged data on two prisms; average imprecision, observed minus smoothed index, is $\pm 14 \times 10^{-7}$ )

$$
\text { [ } \left.\Delta n=\left(n_{t_{2}}-n_{t_{1}}\right) \times 10^{\eta}\right]
$$

Heavy rules in $\Delta n$ columns are located approximately opposite the temperatures of minimum index.

\begin{tabular}{|c|c|c|c|c|c|c|c|c|c|c|c|c|c|c|c|c|c|c|}
\hline \multirow{3}{*}{$\begin{array}{c}\text { Tem- } \\
\text { per- } \\
\text { ature } \\
\left({ }^{\circ} \mathrm{C}\right)\end{array}$} & \multicolumn{16}{|c|}{ Refractive index (referred to dry air at $t^{\circ} \mathrm{C}$ and pressure of $760 \mathrm{~mm}$ of $\mathrm{Hg}$ ) } & \multicolumn{2}{|c|}{ Dispersion } \\
\hline & \multicolumn{2}{|c|}{$\lambda=7065.2 \mathrm{~A}$} & \multicolumn{2}{|c|}{$\lambda=6562.8 \mathrm{~A}$} & \multicolumn{2}{|c|}{$\lambda=5893 \mathrm{~A}$} & \multicolumn{2}{|c|}{$\lambda=5875.6 \mathrm{~A}$} & \multicolumn{2}{|c|}{$\lambda=4861.3 \mathrm{~A}$} & \multicolumn{2}{|c|}{$\lambda=4358.3 \mathrm{~A}$} & \multicolumn{2}{|c|}{$\lambda=4340.5 \mathrm{~A}$} & \multicolumn{2}{|c|}{$\lambda=4046.6 \mathrm{~A}$} & \multirow{2}{*}{$\nu=\frac{n_{D}-1}{n_{F}-n_{C}}$} & \multirow{2}{*}{$\begin{array}{l}\Delta \nu \text { for } \\
1^{\circ} \mathrm{C}\end{array}$} \\
\hline & $n$ & $\begin{array}{c}\Delta n \text { for } \\
1^{\circ} \mathrm{C}\end{array}$ & $n_{C}$ & $\begin{array}{c}\Delta n \text { for } \\
1^{\circ} \mathrm{C}\end{array}$ & $n_{D}$ & $\begin{array}{c}\Delta n \text { for } \\
1^{\circ} \mathrm{C}\end{array}$ & $n_{d}$ & $\begin{array}{c}\Delta n \text { for } \\
1^{\circ} \mathrm{C}\end{array}$ & $n_{F}$ & $\begin{array}{c}\Delta n \text { for } \\
1^{\circ} \mathrm{C}\end{array}$ & $n_{0}$ & $\begin{array}{c}\Delta n \text { for } \\
1^{\circ} \mathrm{C}\end{array}$ & $n_{G^{\prime}}$ & $\begin{array}{c}\Delta n \text { for } \\
1^{\circ} \mathrm{C}\end{array}$ & $n_{h}$ & $\begin{array}{c}\Delta n \text { for } \\
1^{\circ} \mathrm{C}\end{array}$ & & \\
\hline $55 \ldots$ & 1. 4670971 & & 1.4683528 & 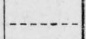 & 1. 4704657 & & 1. 4705277 & & 1. 4753922 & ( & 1,4791364 & & 1,4792999 & & 1. 4822206 & & 66.833 & \\
\hline $50 \ldots$ & - nas & -1.5 & (n...- & -0.9 & & +0.1 & & +0.5 & & +1.5 & & +2.2 & & +2.5 & & +2.8 & & -0.0023 \\
\hline $\begin{array}{l}45 \ldots \\
40 \ldots\end{array}$ & 1.4670986 & -5.7 & 1.4683537 & -5.1 & 1.4704656 & -3.7 & 1.4705272 & -3.3 & 1.4753907 & -1.5 & 1. 4791342 & +0.4 & 1.4792974 & +0.8 & 1.4822178 & +2.2 & \begin{tabular}{c}
66.856 \\
\hdashline
\end{tabular} & -.0035 \\
\hline $35 \ldots$ & 1. 4071043 & -....... & 1. 4683588 & $-\cdots$ & 1. 4704693 & - & 1. 4705305 & ......... & 1.4753922 & & 1. 4791338 & - & 1.4792966 & & 1.4822156 & & 66.891 & \\
\hline $\begin{array}{l}30 \ldots \\
25 \ldots\end{array}$ & 1.4671133 & -9.0 & 1.4683671 & -8.3 & 1.4704757 & -6.4 & 1.4705364 & -5.9 & 1.4753957 & -3.5 & 1.4791348 & -1.0 & 1.4792968 & $-\overline{0.2}$ & 1.4822137 & +1.9 & 66.937 & -.0046 \\
\hline $\begin{array}{l}20 \ldots-. \\
15 \ldots\end{array}$ & 1.4671240 & -10.7 & 1.4683770 & $\begin{array}{c}-9.9 \\
-\end{array}$ & 1.4704833 & -7.6 & 1.4705434 & $\begin{array}{r}-7.0 \\
-\end{array}$ & 1.4754001 & -4.4 & 1.4791365 & -1.7 & 1.4792974 & -6 & 1.4822120 & +1.7 & 66.991 & -.0054 \\
\hline
\end{tabular}


TABLE 4.-Temperature variations in refractivity of "fluorcrown" glass $(E)$ resembling Schott \& Gen. FK4 or 0.3258 (values smoothed by the item-differences method from averaged data on two prisms; average imprecision, observed minus smoothed index, is $\pm 10 \times 10^{-7}$ )

$\left[\Delta n=\left(n_{t_{2}}-n_{t_{1}}\right) \times 10^{7}\right]$

\begin{tabular}{|c|c|c|c|c|c|c|c|c|c|c|}
\hline \multirow{3}{*}{$\begin{array}{l}\text { Tem- } \\
\text { pera- } \\
\text { ture } \\
\left({ }^{\circ} \mathrm{C}\right)\end{array}$} & \multicolumn{8}{|c|}{ Refractive index (referred to dry air at $t^{\circ} \mathrm{C}$ and pressure of $760 \mathrm{~mm}$ of $\mathrm{Hg}$ ) } & \multicolumn{2}{|c|}{ Dispersion } \\
\hline & \multicolumn{2}{|c|}{$\lambda=6562.8 \mathrm{~A}$} & \multicolumn{2}{|c|}{$\lambda=5893 \mathrm{~A}$} & \multicolumn{2}{|c|}{$\lambda=4861.3 \mathrm{~A}$} & \multicolumn{2}{|c|}{$\lambda=4340.5 \mathrm{~A}$} & \multirow{2}{*}{$\nu=\frac{n_{D}-1}{n_{F}-n_{C}}$} & \multirow{2}{*}{$\begin{array}{l}\Delta \nu \\
\text { for } \\
1^{\circ} \mathrm{C}\end{array}$} \\
\hline & $n_{c}$ & $\begin{array}{l}\Delta n \text { for } \\
1^{\circ} \mathrm{C}\end{array}$ & $n_{D}$ & $\begin{array}{l}\Delta n \text { for } \\
1^{\circ} \mathrm{C}\end{array}$ & $n_{P}$ & $\begin{array}{l}\Delta n \text { for } \\
1^{\circ} \mathrm{C}\end{array}$ & $n_{G^{\prime}}$ & $\begin{array}{c}\Delta n \text { for } \\
1^{\circ} \mathrm{C}\end{array}$ & & \\
\hline \multirow{7}{*}{$\begin{array}{l}55 \\
50 \\
45 \\
40 \\
35 \\
30 \\
25 \\
20 \\
15 \\
\end{array}$} & 1. 4768290 & \multirow[b]{2}{*}{+51.1} & 1.4790285 & \multirow{2}{*}{+54.4} & 1. 4841205 & \multirow[b]{2}{*}{+56.9} & 1. 4881473 & \multirow[b]{2}{*}{+57.4} & 65.697 & \multirow{2}{*}{-0.0045} \\
\hline & \multirow{2}{*}{ 1. 4767779} & & \multirow{2}{*}{ 1. 4789741} & & \multirow{2}{*}{ 1. 4840636} & & \multirow{2}{*}{ 1. 4880899} & & \multirow{2}{*}{65.742} & \\
\hline & & \multirow{3}{*}{$\begin{array}{l}+44.5 \\
+41.1\end{array}$} & & +47.0 & & +49.9 & & +53.6 & & -0.0042 \\
\hline & 1.4767334 & & 1.4789271 & $\begin{array}{r}71.0 \\
+42.9\end{array}$ & 1. 4840137 & +460 & 1. 4880363 & \multirow{2}{*}{+53.3} & 65.784 & -0.0038 \\
\hline & 1.4766923 & & 1.4788842 & \multirow{2}{*}{+42.8} & 1.4839677 & & 1.4879830 & & 65.822 & \\
\hline & 1.4766512 & +41.1 & 1. 4788414 & & 1. 4839219 & +45.8 & 1.4879298 & +53.2 & \multirow{2}{*}{65.859} & -0.0037 \\
\hline & & & & & & & & & & \\
\hline
\end{tabular}

TABLE 5.-Temperature variations in refracivily of fluorcrown glass $(F)$ resembling Schott \& Gen. FK2 and FK5 (values smoothed by the item-differences method from averaged data on two prisms; average imprecision, observed minus smoothed index, is $\pm 21 \times 10^{-7}$ )

$\left[\Delta n=\left(n_{t_{2}}-n_{t_{1}}\right) \times 10^{7}\right]$

\begin{tabular}{|c|c|c|c|c|c|c|c|c|c|c|}
\hline \multirow{3}{*}{$\begin{array}{l}\text { Tem- } \\
\text { pera- } \\
\text { ture } \\
\left({ }^{\circ} \mathrm{C}\right)\end{array}$} & \multicolumn{8}{|c|}{ Refractive index (referred to dry air at $i^{\circ} \mathrm{C}$ and pressure of $760 \mathrm{~mm}$ of $\mathrm{Hg}$ ) } & \multicolumn{2}{|c|}{ Dispersion } \\
\hline & \multicolumn{2}{|c|}{$\lambda=6562.8 \mathrm{~A}$} & \multicolumn{2}{|c|}{$\lambda=5893 \mathrm{~A}$} & \multicolumn{2}{|c|}{$\lambda=4861.3 \mathrm{~A}$} & \multicolumn{2}{|c|}{$\lambda=4340.5 \mathrm{~A}$} & \multirow{2}{*}{$\nu=\frac{n_{D}-1}{n_{F}-n_{C}}$} & \multirow{2}{*}{$\begin{array}{l}\Delta \nu \\
\text { for } \\
1^{\circ} \mathrm{C}\end{array}$} \\
\hline & $n_{C}$ & $\begin{array}{c}\Delta n \text { for } \\
1^{\circ} \mathrm{C}\end{array}$ & $n_{D}$ & $\begin{array}{l}\Delta n \text { for } \\
1^{\circ} \mathrm{C}\end{array}$ & $n_{F}$ & $\begin{array}{c}\Delta n \text { for } \\
1^{\circ} \mathrm{C}\end{array}$ & $n_{G^{\prime}}$ & $\begin{array}{l}\Delta n \text { for } \\
1^{\circ} \mathrm{C}\end{array}$ & & \\
\hline & 1. 4878154 & \multirow[b]{2}{*}{-17.0} & 1. 4899206 & \multirow[b]{2}{*}{-15.3} & 1. 4948144 & \multirow[b]{2}{*}{-13.6} & 1. 4986899 & & \multirow[t]{2}{*}{69.999} & \multirow[b]{2}{*}{-0.0036} \\
\hline & 1. 4878324 & & 1. 4899359 & & 1. 4948280 & & 1. 4987005 & -10.6 & & \\
\hline & & -17.7 & & -16.1 & & -14.5 & & -11.7 & $\begin{array}{r}70.035 \\
-\end{array}$ & \multirow{2}{*}{-0.0034} \\
\hline & 1. 4878501 & \multirow{2}{*}{-18.0} & 1. 4899520 & & 1. 4948425 & \multirow{2}{*}{-14.9} & 1. 4987122 & & 70.069 & \\
\hline & 1. 4878681 & & 1. 4899684 & & 1. 4948574 & & 1. 4987243 & & 70.103 & -0.0034 \\
\hline 15 & 1.4878862 & -18.1 & 1. 4899849 & -1 & 1. 4948724 & -15.0 & 1.4987366 & -12.3 & 70.136 & -0.0033 \\
\hline
\end{tabular}

TABLE 6.-Temperature variations in refracivity of fluorcrown glass $(G)$ resembling Schott \& Gen. 0.6781 (values smoothed by the item-differences meihod from averaged data on two prisms; average imprecision, observed minus smoothed index, is $\pm 15 \times 10^{-7}$ )

$\left[\Delta n=\left(n_{t_{2}}-n_{t_{1}}\right) \times 10^{7}\right]$

\begin{tabular}{|c|c|c|c|c|c|c|c|c|c|c|}
\hline \multirow{3}{*}{$\begin{array}{l}\text { Tem- } \\
\text { pera- } \\
\text { ture } \\
\left({ }^{\circ} \mathrm{C}\right)\end{array}$} & \multicolumn{8}{|c|}{ Refractive index (referred to dry air at $t^{\circ} \mathrm{C}$ and pressure of $760 \mathrm{~mm}$ of $\mathrm{Hg}$ ) } & \multicolumn{2}{|c|}{ Dispersion } \\
\hline & \multicolumn{2}{|c|}{$\lambda=6562.8 \mathrm{~A}$} & \multicolumn{2}{|c|}{$\lambda=5893 \mathrm{~A}$} & \multicolumn{2}{|c|}{$\lambda=4861.3 \mathrm{~A}$} & \multicolumn{2}{|c|}{$\lambda=4340.5 \mathrm{~A}$} & \multirow{2}{*}{$\nu=\frac{n_{D}-1}{n_{F}-n_{C}}$} & \multirow{2}{*}{$\begin{array}{c}\Delta \nu \\
\text { for } \\
1^{\circ} \mathrm{C}\end{array}$} \\
\hline & $n_{c}$ & $\begin{array}{c}\Delta n \text { for } \\
1^{\circ} \mathrm{C}\end{array}$ & $n_{D}$ & $\begin{array}{c}\Delta n \text { for } \\
1^{\circ} \mathrm{C}\end{array}$ & $n_{F}$ & $\begin{array}{c}\Delta n \text { for } \\
1^{\circ} \mathrm{C}\end{array}$ & $n_{G^{\prime}}$ & $\begin{array}{l}\Delta n \text { for } \\
1^{\circ} \mathrm{C}\end{array}$ & & \\
\hline \multirow{6}{*}{$\begin{array}{l}55 \\
50 \\
45 \\
40 \\
35 \\
30 \\
25 \\
20 \\
15\end{array}$} & 1. 4910265 & \multirow{2}{*}{-19.1} & 1. 4931528 & \multirow{2}{*}{-17.2} & 1. 4980910 & \multirow{2}{*}{-15.4} & 1. 5019926 & \multirow{2}{*}{-14.1} & 69.807 & \multirow{2}{*}{-0.0039} \\
\hline & 1.4910456 & & 1.4931700 & & 1.4981064 & & 1.5020067 & & 69.846 & \\
\hline & 1.4910653 & -19.7 & 1.4931877 & -17.7 & 1.4981223 & -15.9 & 1.5020211 & -14.4 & 69.886 & -0.0040 \\
\hline & 1.4910853 & \multirow{2}{*}{$\begin{array}{l}-20.0 \\
-20.2\end{array}$} & 14932056 & \multirow{3}{*}{$\begin{array}{l}-17.9 \\
-18.0\end{array}$} & 4981383 & \multirow{3}{*}{$\begin{array}{l}-16.0 \\
-16.1 \\
\end{array}$} & 5020356 & -14.5 & 60.098 & -0.0042 \\
\hline & & & & & & & $\begin{array}{c}1.0020000 \\
-1.20\end{array}$ & -14.6 & 0.920 & -0.0044 \\
\hline & 1. 4911055 & $-\ldots$ & 1. 4932236 & & 1. 4981544 & & 1.5020502 & & 69.972 & \\
\hline
\end{tabular}

$644098-45-9$ 


\section{Journal of Research of the National Bureau of Standards}

The tabulated data extend over a near-room range of temperatures, at which water-jackets are commonly used, because the temperature coefficients of the refractometers on which such standards may be used are seldom, if ever, adequately known. This is a matter of primary importance for an instrument which, like the Butyro refractometer, is to be used at relatively high working temperatures on fats and waxes, some of which are solids at ordinary room temperatures. In such cases it is recommended that refractometers bs adjusted on solid samples at the working temperature in use. In this way one obviates corrections relative to a known performance at standard temperature. ${ }^{3}$ Some fluorcrown glasses seem especially suitable for these standards because their temperature coefficients of refractivity are negligibly small. Glasses A and D have their minima of refractivity at room temperatures. The temperatures differ for various wavelengths and are indicated approximately by the rules in the $\Delta n$ columns of tables 1 and 3. The refractive-index data here given will facilitate the making of refractive-index standards from similar glasses by greatly reducing the number of precise index measurements that will be required in their calibration over a suitable range of temperatures.

\section{SURFACE INSTABILITY}

The use of fluorcrown glasses for refractive-index standards is, however, not entirely satisfactory. Unfortunately, many of them are relatively soft and the polished surfaces are easily scratched. In some cases there is a far more serious tendency to weather or disintegrate in such manner that the surface changes its refractive index and no longer corresponds to the index of the main body of the glass as measured on the spectrometer. Whenever this occurs, repolishing is imperative. The effect of weathering may first be noticed as a poorly defined critical border or residual chromaticity when one attempts to use the compensator. Later, as a more striking manifestation, multiple critical borders are seen. These correspond apparently to different glasses in different parallel layers near the surface. For the glass A, of index 1.4611, the lowest here considered, it is found that repolishing is necessary after a very few months. After a period of 2 years the glass $\mathrm{D}$, index 1.4705 , showed some indications of surface index changes and the glasses $\mathrm{B}$ and $\mathrm{C}$, index 1.4623 , presented slight evidence of this sort. In both these cases the changes were unmistakable after 5 years. For the other glasses no changes were optically detectible after 9 years. One surface of each prism was resurfaced after 7 years, but it is not certain that this was necessary in any case (except for the 1.4611 glass) for their accurate use in refractometry with a precision of \pm 1 or $2 \times 10^{-5}$ as the maximum probable error in index determinations. Nevertheless, experience with these standards suggests that it is advisable to test the stability of fluorcrown glasses before precise calibrations are undertaken.

The optical evidences of the changes that take place on and near the surfaces of the prisms of glasses A, B, C, and D are so nearly systematic in their approximate regularity and interrelations that a detailed report thereon is given in table 7 and figure 1. Possibly there are only

3 See the author's discussion of temperature effects in critical-angle refractometry, J. Research NBS 30 317 (1943) RP1535. 
TABLE 7.-Refractometric measurements on products formed by surface weathering of fluorcrown optical glasses

\begin{tabular}{|c|c|c|c|c|c|c|c|c|c|c|c|c|}
\hline \multirow{2}{*}{ Critical border line } & \multicolumn{3}{|c|}{ Glass A } & \multicolumn{4}{|c|}{ Glass $\mathrm{B}=\mathrm{C}$} & \multicolumn{5}{|c|}{ Glass D } \\
\hline & a 1938 & 1944 & $n_{P}-n_{C}$ & a 1938 & 1942 & 1944 & $n_{F}-n_{C}$ & a 1938 & 1940 & 1942 & 1944 & $n_{F}-n_{C}$ \\
\hline $\begin{array}{l}\text { Principal } \\
\text { First bright-line "doublet" }\end{array}$ & $\begin{array}{l}1.4611 \\
1.4622 \\
1.4626\end{array}$ & 1.4611 & $\begin{array}{r}0.0069 \\
.0082 \\
\end{array}$ & 1.4622 & 1.4622 & $\begin{array}{l}1.4622 \\
1.4636 \\
1.4638\end{array}$ & $\begin{array}{r}0.0070 \\
.0082 \\
\end{array}$ & $\begin{array}{l}1.4705 \\
1.4718 \\
1.4723\end{array}$ & $\begin{array}{l}1.4705 \\
\text { 1. } 4720\end{array}$ & $\begin{array}{l}1.4704 \\
1.4726 \\
1.4728\end{array}$ & $\begin{array}{l}1.4704 \\
1.47727\end{array}$ & $\begin{array}{r}0.0070 \\
.0090\end{array}$ \\
\hline Second bright-line "doublet"-.. & 1.4654 & $\begin{array}{l}1.4648 \\
1.4651\end{array}$ & $\begin{array}{l}.0081 \\
.0081\end{array}$ & 1.4649 & 1.4657 & $\begin{array}{l}1.4000 \\
1.4655 \\
1.4659\end{array}$ & .0086 & $\begin{array}{l}1.4723 \\
1.4767 \\
1.4773\end{array}$ & $\begin{array}{l}1.4723 \\
1.4766 \\
1.4774\end{array}$ & $\begin{array}{l}1.4778 \\
1.4770 \\
1.4773\end{array}$ & $\begin{array}{l}1.4770 \\
1.4771 \\
1.4776\end{array}$ & .0083 \\
\hline Third bright-line "doublet" & 1.4706 & & & 1.4676 & 1.4684 & $\begin{array}{l}1.4682 \\
1.4686\end{array}$ & .0084 & & & & & \\
\hline Fourth bright-line “doublet”.- & 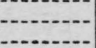 & 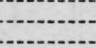 & ........ & 1.4722 & & $\begin{array}{l}1.4722 \\
1.4729\end{array}$ & .0089 & & & (n) & 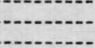 & (n) \\
\hline
\end{tabular}

- Numerous measurements of $n_{D}$ made from 1929 to 1938 on various critical-angle refractometers were averaged. 
a limited number of relatively stable glasses of the fluorcrown type, and after weathering takes place the surface layer may change to some one of the relatively stable glasses that are higher in index. Moreover, this process seems capable of sluggish progression so that one test prism sometimes gives not only the principal border line but as many as eight faint critical edges, simultaneously visible, and some of them are found to correspond approximately to the border lines seen with other glasses of higher index.

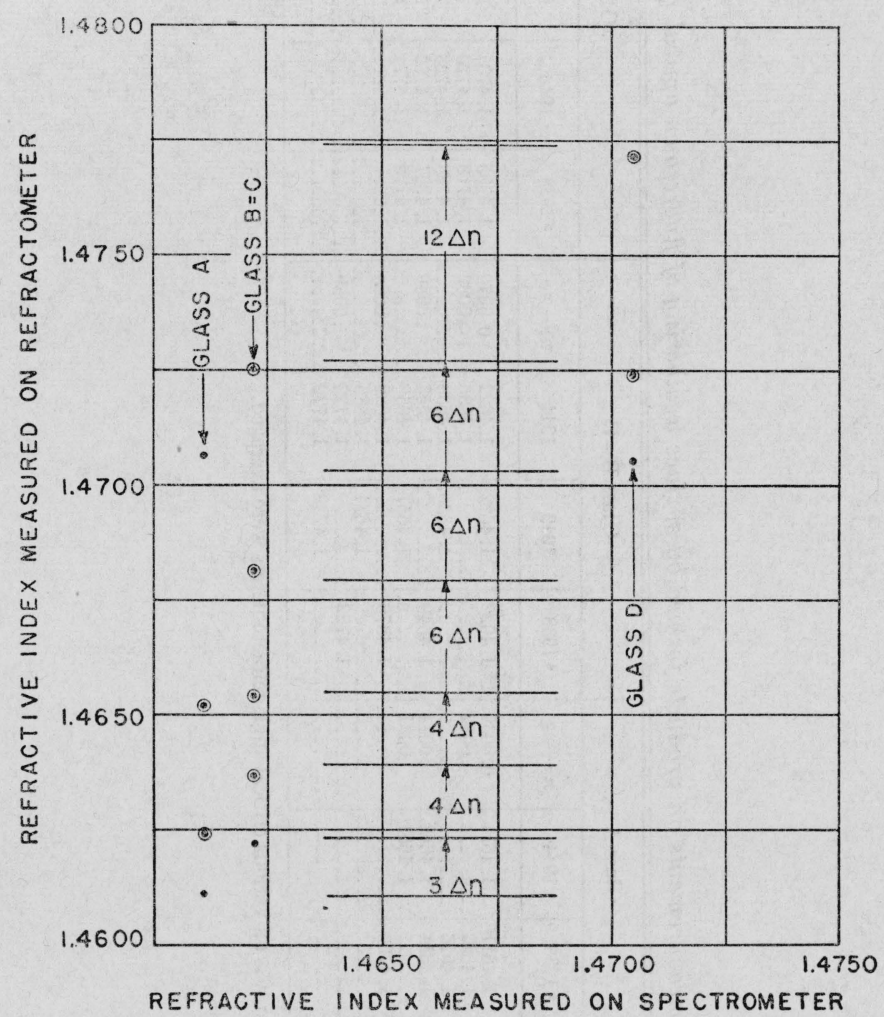

FIGURE 1.-Refractivity of three fluorcrown optical glasses and of the products formed by their surface weathering.

Numerous measurements of $n_{\mathrm{D}}$ made from 1929 to 1944 on various critical-angle refractometers were averaged. Encircled points represent averages for two distinet critical borderlines. The average separation of the "doublets" in these eight instances is $\Delta n=0.0004$.

It is reasonable to suppose that loss of fluorine is an important element in the weathering process, and in this connection it should be noted that the dispersion, $n_{F}-n_{C}$, for all of the weathered layers is found to be as high as 0.0080 to 0.0090 , whereas that of the main body of these glasses is only 0.0070 . In fact, the dispersions of the weathered layers approximate those of lowest-index silicate glasses without fluorine.

The only added critical edges that can be readily observed in the field of a refractometer, together with the edge corresponding to the main volume of the glass, are those corresponding to surface layers of higher index. These edges appear in the otherwise dark portion of . the field. Each thin layer on the sample surface gives a narrow-slit 


\section{Standards of Fluororown Glass}

effect and confines the brightly illuminated area to a narrow line of which one side is a critical border and the other is a geometrical limit imposed by the width of the layer.

This interpretation of the observed phenomena was confirmed by observations on a composite prism made by cementing thin layers of different-index glasses on the surface of a standard sample. Also, similar phenomena were observed on two crown-flint prisms $\left(n_{D}=\right.$ 1.5296) that, after polishing, were annealed in a new furnace where lead oxide was inadvertently present on some of the iron plates. Three added critical edges were well-defined for the $C, D$, and $F$ lines, and they corresponded to layers having indices $n+\Delta n, n+2 \Delta n$, and $n+4 \Delta n$, where $\Delta n=0.00004$ and differences in dispersion, if any, were too small to be detected.

Remembering that these glasses $\mathrm{A}, \mathrm{B}=\mathrm{C}$, and $\mathrm{D}$, which are found to exhibit this multiple-index behavior, resemble the Schott glasses FK1 and FK3 in their index and dispersion, it is interesting to note from the meager data on compositions, as given on page 314 of Glastechnische Tabellen, that these fluorcrowns FK1 and FK3 differ from FK2 and FK5 in that they contain aluminum.

It is not implied that the multiple edges observed on some of these glasses are necessarily present when other similar glasses are used. In fact, three prisms of unknown antecedents, having indices of $1.46541,1.47952$, and 1.49776 , showed no multiple edges when examined. They had been surfaced at least 3 months when tested, but no more definite knowledge concerning them is now obtainable. It is possible, also, that some improvements in the weathering characteristics of the fluorcrown glasses have been effected by the manufacturers in recent years. Nevertheless, there is probably in existence much unused glass of melts like those cited in this report. Consequently, care should be exercised by refractometrists when fluorcrown glasses are selected or used for standards in precise refractometry.

\section{EFFECT OF TEMPERATURE ON RESONANCE FREQUENCY}

Entirely aside from their value in refractometry, the data given in tables 1 to 6 are of theoretical interest because of their evidence regarding the effect of temperature on the resonance frequencies of vibration in the ultraviolet region. With the exception of glass E, these glasses differ from most optical glasses in that their temperature coefficients of refractive index are, in general, negative. In this respect they resemble liquids and most crystals. In such cases the normal effect of temperature on density is said to predominate over that ascribed to shifting of the absorption band as temperature changes.

Tables 1 and 3 and figure 2 show that the condition for zero temperature coefficient of index in these glasses is a function of temperature and of wavelength, so that the minimum of change in index can in some cases, as for glass D, occur near $55^{\circ}$ for red light, near $35^{\circ}$ for blue, and well below $15^{\circ}$ for violet light. Obviously, at higher temperatures all these glasses can be expected to have positive temperature coefficients of refractive index as do optical glasses in general. In all cases for these data the temperature coefficients of index increase algebraically (1) as the temperature increases and (2) as wavelength is shortened, just as should be the case if the critical frequency becomes lower when the temperature rises. From figure 2 
it is evident that in some cases wholly erroneous conclusions regarding the temperature coefficients of crown glass at room temperatures may easily be drawn from index data taken".." gn glass over a wide interval from room to furnance temperatures.

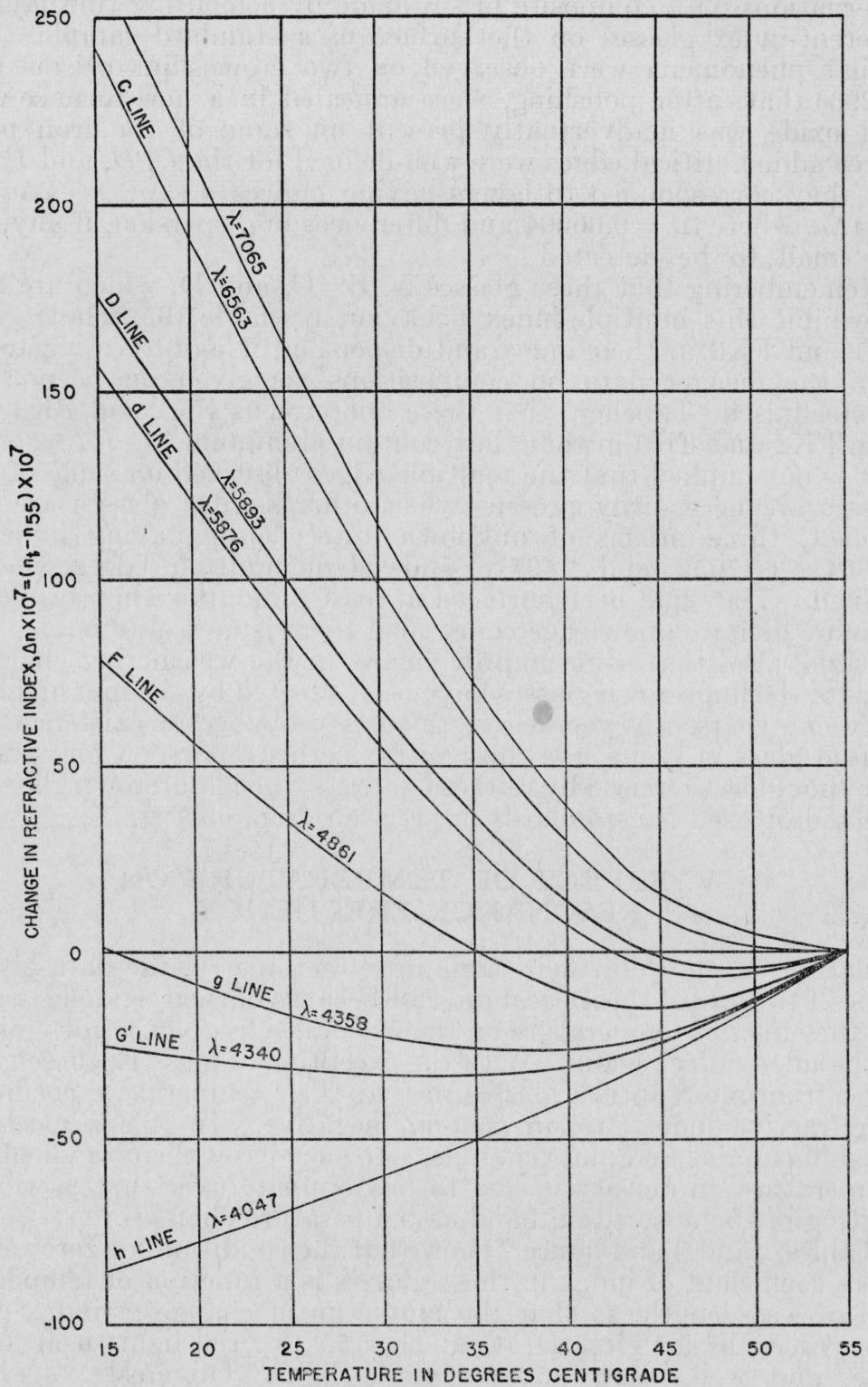

FIGURE 2.-Minimum refractive index of a fluorcrown glass as a function of temperature and wavelength (data from table 3 ).

For light of wavelength $\lambda=4047$ A this glass has a positive temperature coefficient of refractivity at all room temperatures as indicated by the positive slope of the lowest curve, whereas for $\lambda=7065 \mathrm{~A}$ the coefficient is negative. For most intermediate wavelengths, there is a zero slope and a minimum refractivity at some near-room temperature.

Washington, February 10, 1945 . 
NATIONAL BUREAU OF STANDARDS, WASHINGTON 25, D. C.

Send me the Mathematical Tables marked $\times$ below. I enelose remittance to cover the cost.

\begin{tabular}{|c|c|c|c|c|}
\hline Mark X & Title of publication & $\begin{array}{l}\text { United States and } \\
\text { its possessions, } \\
\text { and countries ex- } \\
\text { tending franking } \\
\text { privillege }\end{array}$ & Other countries & Amount enclosed \\
\hline 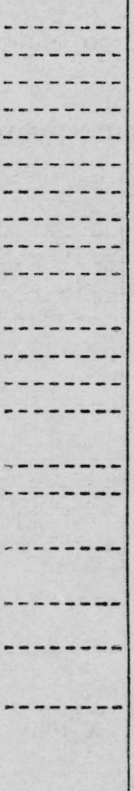 & 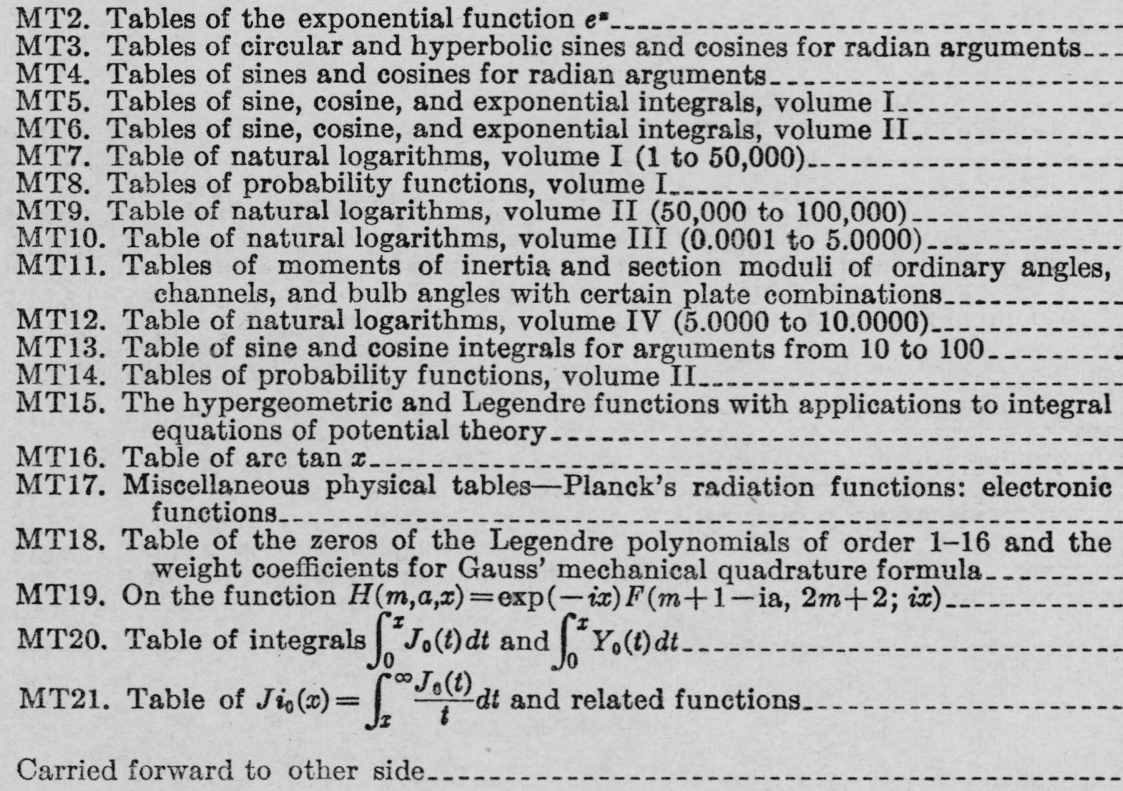 & $\begin{array}{r}\$ 2.00 \\
2.00 \\
2.00 \\
2.00 \\
2.00 \\
2.00 \\
2.00 \\
2.00 \\
2.00 \\
2.00 \\
2.00 \\
2.00 \\
2.00 \\
2.00 \\
2.00 \\
1.50 \\
.25 \\
.25 \\
.25\end{array}$ & $\begin{array}{r}\$ 2.50 \\
2.50 \\
2.50 \\
2.50 \\
2.50 \\
2.50 \\
2.50 \\
2.50 \\
2.50 \\
2.50 \\
2.50 \\
2.50 \\
2.50 \\
2.50 \\
2.50 \\
1.75 \\
.30 \\
.30 \\
.30 \\
.30\end{array}$ & 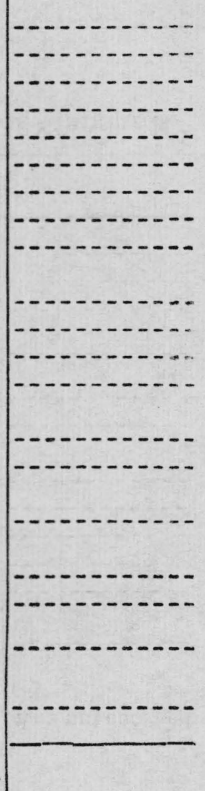 \\
\hline
\end{tabular}




\begin{tabular}{|c|c|c|c|c|}
\hline Mark X & Title of Publication & $\begin{array}{l}\text { United States and } \\
\text { its possessions, } \\
\text { and countries ex- } \\
\text { tending franking } \\
\text { privilege }\end{array}$ & Other countries & Amount enclosed \\
\hline - & $\begin{array}{l}\text { Brought forward from other side. } \\
\text { MT22. Table of coefficients in numerical integration formulae } \\
\text { MT23. Table of Fourier coefficients } \\
\text { MT24. Coefficients for numerical differentiation with central differences } \\
\text { MT25. Seven-point Lagrangian integration formulas } \\
\text { MT26. A short table of the first five zeros of the transendental equation, } \\
\text { MT27. Table of coefficients for inverse interpolation with central differences } J_{0}(x) Y_{0}(k x)-J_{0}(k x) Y_{0}(x)=0 \\
\text { MT28. Table of } f_{n}(x)=\frac{n !}{(x / 2)^{n}} J_{n}(x) \\
\text { MT29. Table of coefficients for inverse interpolation with advancing differences } \\
\text { MT30. A new formula for inverse interpolation } \\
\text { MT31. Coefficients for interpolation within a square grid in the complex plane. } \\
\text { MT32. Table of coefficients for differences in terms of the derivatives } \\
\text { Total remittance. }\end{array}$ & $\begin{array}{r}\$ 0.25 \\
.25 \\
.25 \\
.25 \\
.25 \\
.25 \\
.25 \\
.25 \\
.25 \\
.25 \\
.25\end{array}$ & $\begin{array}{r}\$ 0.30 \\
.30 \\
.30 \\
.30 \\
.30 \\
.30 \\
.30 \\
.30 \\
.30 \\
.30 \\
.30\end{array}$ & 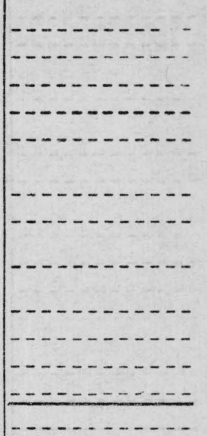 \\
\hline
\end{tabular}

Remittance should be in form of post-office money order, or check, and made "payable to the order of the "National Bureau of Standards" in United States currency

Send to

Number and Street

City, Zone, and State 


\section{MATHEMATICAL TABLES}

Attention is invited to a series of publications prepared by the Project for the Computation of Mathematical Tables conducted by the Federal Works Agency, Work Projects Administration for the City of New York, under the sponsorship of the National Bureau of Standards. The tables which have been made available through the National Bureau of Standards are listed below. A list of other WPA tables obtainable elsewhere will be sent by the Bureau on request.

There is included in this list a publication of the hypergeometric and Legendre functions (MT15), prepared by the Bureau.

MT1. Table of the First Ten Powers or the Integers From 1 to 1,000: (1938) VIII + 80 pages; heavy paper cover. Out of print.

MT2. Tables or the Exponential Function $e^{z}$ : The ranges and intervals of the argument and the number of decimal places in the entries are given below:

$\begin{array}{ccc}\text { Range of } x & \text { Interval of } x & \text { Decimals given } \\ -2.5000 \text { to } 1.0000 & 0.0001 & 18 \\ 1.0000 \text { to } 2.5000 & .0001 & 15 \\ 2.500 \text { to } 5.000 & .001 & 15 \\ 5.00 \text { to } 10.00 & .01 & 12\end{array}$

(1939) XV +535 pages; bound in buckram, $\$ 2.00$.

MT3. Tables of Circular and Hyperbolic Sines and Cosines for Radian Arguments: Contains 9 decimal place values of $\sin x, \operatorname{ccs} x, \sinh x$, and $\cosh x$ for $x$ (in radians) ranging from 0 to 2 at intervals of 0.0001 . (1939) XVII +405 pages; bound in buckram, $\$ 2.00$.

MT4. Tablfs or Sines and Cosines for Radian Arguments: Contains 8 decimal place values of sines and cosines for racian arguments ranging from 0 to 25 at intervals of 0.001 . (1940) XXIX +275 pages; bound in buckram, $\$ 2.00$.

MT5. Tables of Sine, Cosinr, and Exponential Intrgrals, Volume I: Values of these functions to 9 places of decimals from 0 to 2 at intervals of 0.0001 . (1940) XXVI +444 pages; bound in buckram, $\$ 2.00$.

MT6. Tables or Sine, Cosine, and Exponential Intrgrats, Volume II: Values of these functions to 9,10 , or 11 significant figures from 0 to 10 at intervals of 0.001 with auxiliary tables. (1940) XXXVII + 225 pages; bound in buckram, $\$ 2.00$.

MT7. Taele or Naturas Logarithms, Volume I: Logarithms of the integers from 1 to 50,000 to 16 places of decimals. (1941) XVIII + 501 pages; bound in buckram, $\$ 2.00$.

MT8. Tables of Probability Functions, Volume I: Values of these functions to 15 places of decimals from 0 to 1 at intervals of 0.0501 and from 1 to 5.6 at intervals of 0.001 . (1941) XXVIII + 302 pages; bound in buckram, $\$ 2.00$.

MT9. Table op Natural Logarithms, Volume II: Logarithms of the integers from 50,000 to 100000 to 16 places of decimals. (1941) XVIII + 501 pages; bound in buckram, $\$ 2.00$.

MT10. TABLE of Natural Logarithms, Volume III: Logarithms of the decimal numbers from 0.0001 to 5.0000 , to 16 places of decimals. (1941) XVIII + 501 pages; bound in buckram, $\$ 2.00$.

MT11. Tables of the Moments or Inertia and Section Moduli of Ordinary Angles, Chan. nels, and Bulb Angles with Certain Plate Combinations: (1941) XIII + 197 pages; bound in green cloth. $\$ 2.00$.

MT12. Table of Natural Logarithms, Volume IV: Logarithms of the decimal numbers from 5.0000 to 10.0000 , to 16 places of decimals. (1941) XXII + 506 pages; bound in buckram, $\$ 2.00$.

MT13. Tablz of Sinz and Cosine Integrals por Arguments prom 10 to 100: (1942) XXXII + 185 pages; bound in buckram, $\$ 2.00$.

MT14. Tables of Probability Functions, Volume II: Values of these functions to 15 places of decimals from 0 to 1 at intervals of 0.0001 and from 1 to 7.8 at intervals of 0.001 . (1942) XXI +344 pages; bound in buckram, $\$ 2.00$.

MT15. The Hypergeometric and Legendre Functions With Applrcations to Intrgral Equa. tions or Potential Theory. By Chester Snow, National Bureau of Standards.I Reproduced from original handwritten manuscript. (1942) VII +319 pages, bound in heavy paper cover. $\$ 2.00$.

MT16. TABLE of ARC TAN $x$ : Table of inverse tangents for positive values of the angle in radians. Second central differences are included for all entries. $x=[0(.001) 7(.01) 50(.1) 300(1) 2,000(10)$ 10,$000 ; 12 D \rrbracket(1942) \mathrm{XXV}+169$ pages; bound in buckram, $\$ 2.00$.

[Continued on p. 4 of cover》 
MT17. Miscrllangous Physical Tablfs: Plancx's Radiation Functions (Otiginally published in the Journal of the Optical Sociaty of America, February 1940); and Electronic Functions. (1941) VII+ 58 pages; bound in buckram, $\$ 1.50$.

MT18. Tabie op the Zroos of the Legendre Polynomials op Order 1-16 and the Weight Corppicients por Gaujs' Mechanical Quadrature Formula. (Reprinted from Bul. Amer. Mathematical Society, October 1942.) 5 pages, with cover, 25 cents.

MT19. On the Function $H(m, a, x)=\exp (-i x) F(m+1-i a, 2 m+2 ; i x)$; with table of the confluent hypergeometric function and its first derivative. (Reprinted from J. Math. Phys., December 1942.) 20 pages, with cover, 25 cents.

MT20. Table of Integrals $\int_{0}^{x} J_{0}(t) d t$ and $\int_{0}^{z} Y_{0}(t) d t$. (Reprinted from J. Math. Phys., May 1943.) 12 pages, with cover, 25 cents.

MT21. Table of $J 1_{0}(x)=\int_{z}^{\infty} \frac{J_{0}(t)}{t} d t$ and Related Functions. (Reprinted from J. Math. Phys., June 1943.) 7 pages, with cover, 25 cents.

MT22. Table of Coepricients in Numzrical Intrgration For mulaz. (Reprinted from J. Math. Phys., June 1943.) 2 pages, with cover, 25 cents.

MT23. Table op Fourier Compricients. [(Reprinted from J. Math. Phys., Sept. 1943.) 11 pages, with cover, 25 cents.

MT24. Corfpicients por Numerical Dipperentiation With Central Dipferences. (Reprinted from J. Math. Phys., Sept. 1943.) 21 pages, with cover, 25 cents.

MT25. Seven-Point Lagrangian Intrgratiolv Formulas. (Reprinted from J. Math. Phys., Dec. 1943.) 4 pages, with cover, 25 cents.

MT26. A Short Table or the First Five Zeros op the Transcendental Equation, $J_{0}(x) Y_{r}(k x)-J_{0}(k x) Y_{0}(x)=0$. (Reprinted from J. Math. Phys., Dec. 1943.) 2 pages, with cover, 25 cents.

MT27. Table of Coefricients for Inverse Interpolation with Central Differences. (Re. printed from J. Math. Phys., Dec. 1943.) 15 pages, with cover, 25 cents.

MT28. TABLE of $f_{n}(x)=\frac{n !}{(x / 2)^{n}} J_{n}(x)$. (Reprinted from J. Math. Phys., Feb. 1944) 16 pages, with cover, 25 cents.

MT29. Table or Corppicients for Inverse Interpolation with Advancing Difrerences (Reprinted from J. Math. Phys., May 1944) 28 pages, with cover, 25 cents.

MT30. A New Formula for Inverse Interpolation. (Reprinted from Bul. Amer. Mathe. matical Society, Aug. 1944.) 4 pages, with cover, 25 cents.

MT31. Corppicients for Interpolation Within a Square Grid in the Complex Plane. (Re. printed from J. Math. Phys, Aug. 1944). 11 pages, with cover. 25 cents.

MT32. Table of Corpricients por Difperences in Trrms of the Derivatives. (Reprinted from J. Math. Phys., Nov. 1944.) 4 pages, with cover, 25 cents.

Payment is required in advance. Make remittance payable to the "National Bureau of Standards" and send with order, using the blank form facing page 3 of the cover.

A mailing list is maintained for those who desire to receive announcements regarding new tables as they become available. 